\title{
先天性内反足に対する踵骨頸部外転骨切り術の経験
}

$\begin{array}{llllll}\text { 九州大学整形外科 } & & & & \\ \text { 野 村 茂 } & \text { 治・藤 } & \text { 井 } & \text { 敏 } & \text { 男 } \\ \text { 熊 谷 洋 } & \text { 幸・近 } & \text { 藤 } & \text { 正 } & \text { 一 } \\ \text { 高 妻 雅 } & \text { 和 } & & & \\ \text { 宮崎県立病院整形外科 } & & & & \\ \text { 松 尾 } & \text { 隆 } & & & \end{array}$

\section{Abductive Osteotomy of Calcaneal Neck for Relapsed Club Foot.}

\section{By}

\author{
S. Nomura, T. Fujii, H. Kumagaya, S. Kondo \\ and M. Kôzuma
}

Department of Orthopaedic Surgery, Faculty of Medicine, Kyushu University, Fukuoka.

\section{T. Matsuo}

Orthopaedic Surgery, Miyazaki Kenritsu Hospital, Miyazaki.

For the correction of the relapsed club foot, Evans' method was prefered. The results, after this procedure, were satisfactory. But the fusion of the calcaneocuboidal joint leads to a variable but inevitable loss of tarsal motion. Another problem is postoperative pseudoarthrosis of the calcaneocuboidal joint for four or five years old cases.

The disadvantages of Evans' operation have led us to try a new method. It preserves the calcaneocuboidal joint, it requires a abductive osteotomy of the calcaneal neck.

In selected instances, this has been a very helpful addition to the surgical method for club foot.

\section{緒}

先天性内反足の治療は早期の corrective cast, 後 方解離術の導入により大幅な改善をみたが，一方いま だに遺残変形の徵候 は随所にみられ，内旋歩行の発 現，凹足を伴なう足短縮，変形再発之問題は多く，い ずれかに後療法でその弱点をカバーしているのあ事実 である. われわれは年長児遺残変形に対しては salvage 手術として Evans 手術を行なってきたが，後 療法むいらず，再発むきたさない，術後可動性も良好 という優れた手術であるとの評価を得てきた.しかし ながらこの手術は踵立方関節切除固定を行なう訳で, これによる距踵舟関節の動きに対する影響は否定出来 ず，また年少者に行なう場合は軟骨部分が多く，切除
範囲が大きくなり過矯正を起こす危険がある

これらの点を解決すべく, 踵立方関節は温存し, 踵 骨頸部の外転骨切り術を行ない, いささかの知見を得 たので報告する．

$$
\text { 対 象 }
$$

昭和 51 年より 52 年 6 月までに踵骨頸部外転骨切り 術を行なった 5 例 6 足を対象とした. 手術時年令は 2 才 8 力月より 9 才まで, 平均 6 才 1 力月である. 経過 観察期間 は 3 力月より 1 年 5 力月で平均 7 力月であ る. 今回の手術までの治療歴は. 1 例のみ保存的治療 で，他の 4 例 5 足は何らかの 手術的処置を受けてい た. 

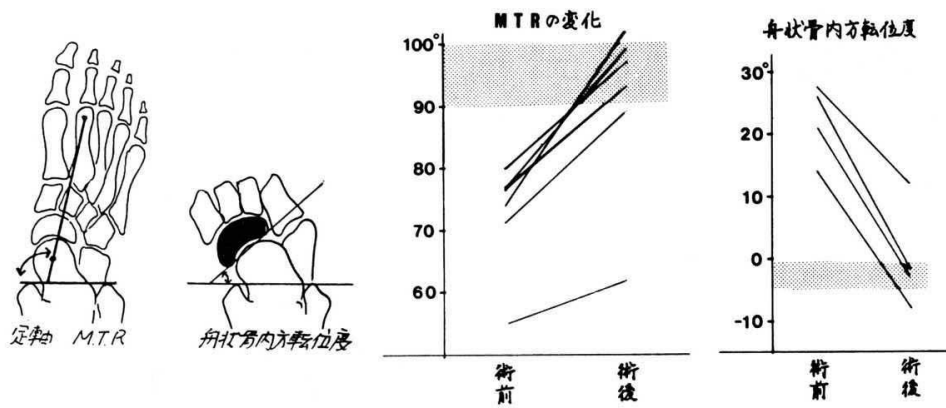

図 1

\section{手 術方 法}

対象症例全例に尖足変形はないため後方解離行は行 なっていない. 手術は Evans 手術之同様に舟状骨結 節より内果下方に向う弧状切開を加え後脛骨筋を Z 状 に切離, 次いで舟状骨側に接し三角靯帯脛舟部, 後脛 骨筋腱鞘, spling ligament を切離, さらに長 趾屈 筋, 長践趾屈筋腱々鞘の切離および必要に応じ腱延長 を行なう。

次に外側切開を加え腓骨筋，短趾伸筋を分けて踵骨 前方を充分に出し楔状骨切りを行なう. 固定はステー プルを用いている.

後療法は術後大腿から足尖までのギプスを 6 週，そ の後 4 週間下腿ギプスを行なう．その後は夜間のみ矯 正位保持装具を $3 \sim 6$ 力月間使用する.

\section{評価法及び結果}

経過観察期間が短いため手術成績について論ずるに 至っておらず改めて報告する.今回は術前後の前足部 立位前後像で足軸を測定し効果判定を行なった。 また 舟状骨転位の変化は図 1 のごとき方法にて測定した.

結果は足軸をみる MTR は術前平均 77.3 度之内軽 しているが術後は 90.3 度と明らかな改善をみる. 舟 状骨内転度は 5 才以上の症例で測定し, 術前 18.8 度, 術後 0 度と改善をみる.

症例に供覧する。

\section{症例 1 \\ 両先天性内反足}

生後 9 日目に来院, cast 治療を開始, 内転内反変 形矯正後, 生後 6 力月に後方解離術を受ける. 術後 4 年左右し線では良好な足根骨の関係を示すが著明なみ かけ上の内捻，四足変形をみる．5才時 midtarsal reledse を行なうも内転変形矯正は不充分で 5 才 8 力
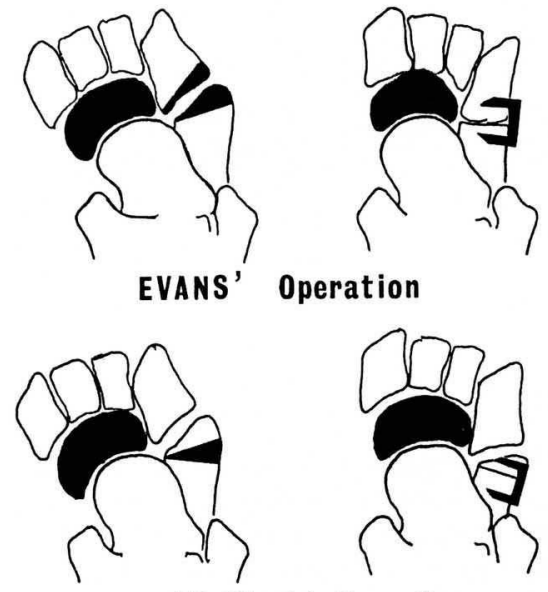

蹱骨頚部外䎐骨切川術

図 2

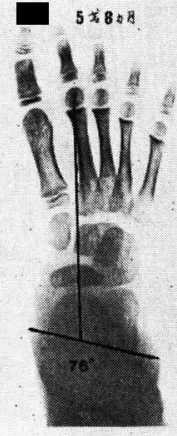

術. 前

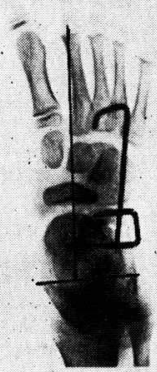

埇中コントローン

図 3

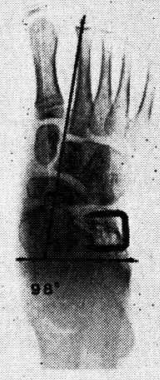

街很 4 蚂
月に内側解離 および 踵骨頸部外転骨切り術を行なっ た. 右側のレントゲンで足軸は術前 76 度と強い内転 をみるが術後は 98 度と充分外転した（図 3 ）。 


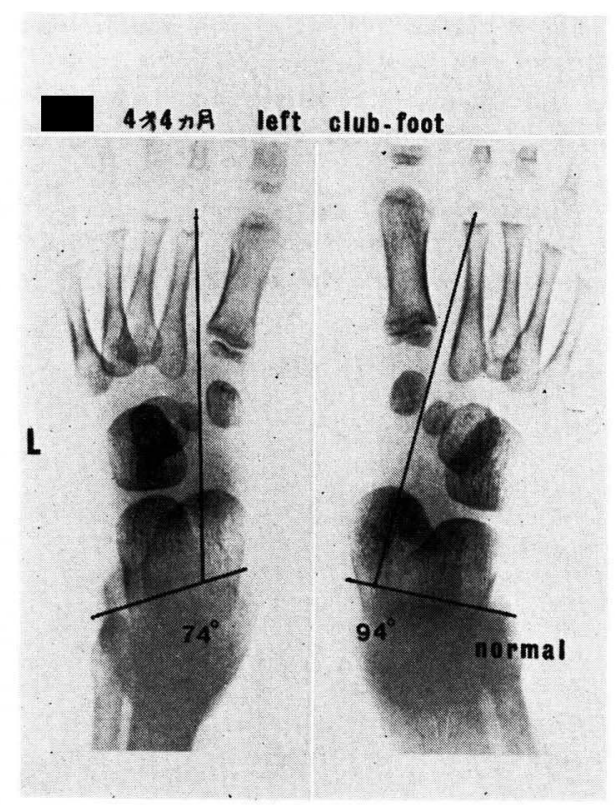

図 4

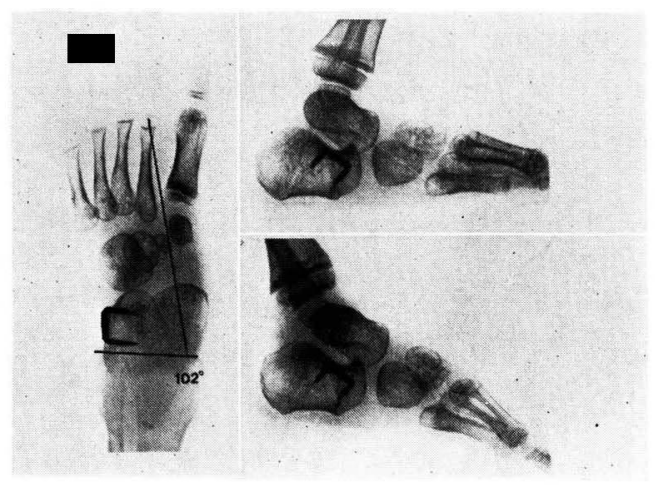

図 5

\section{症例 2}

左内反足

生後 10 日目に来院， cast により内転内反を矯正の 後, 尖足も cast 矯正し得た. その後夜間装具を着用 していたが 3 才頃より内転変形がみられ，以後走行時 内旋歩行が著明で転倒しやすくなる．レ線であ足軸は 74 度と強い内転をみる. 図 4 術後 3 力月のレ線では 足軸は 102 度と外転し, 底背屈も良好である（図 5 )。

\section{考}

\section{案}

Elmslie が述べるごとく内反足変形の主要因は距踵 舟開節の位置異常である. 年長児内反足では転部組織
の拘縮に加え 2 次性の骨変化が起こっている．このよ うな症例では踵立方関節をはじめとする外側の障害を 上り除かねば長期にわたる後療法が必要となる.

外側に対しての処置について Fredenhagen が Scherb の手術を紹介しているが，著者らの調べた範囲 では 1902 年に Ogston A. が距骨頭と踵骨前方およ び立方骨の骨核搔爬を 1934 年に Curtis F. E. が距骨 頭之踵骨前方部分の軟骨下海綿骨の切除を, 1958 年に Johanning K. は立方骨の骨核搔爬術を行なってい る. そして1961 年に Evans が踵立方関節切除固 定という後療法のいらない画期的方法を紹介した.

Evans は長期観察例で踵立方関節切除固定による 障 害はないと述べているが，1973 年 Lichtblau S. は midtarsal の動きを障害するという考えより立方骨の 関節転骨はさわらずに，踵骨前方部分の切除を提唱し ている.しかしての手術では外側骨性アーチが保持出 来ないため, 尖足矯正不充分な症例では舟底足変形を 作る危険がある.

Lichtblau の手術方法は賛成出来ないとしても Evans 手術にはいくつかの問題はある.すなわち(1) 踵立方関節切除固定という他の变形をつくる. (2)内方 発育が大きくなり valgus 変形をつくる. (3)subtalar motion 抢よび tarsal motion の影響, (4)年少者て は偽関節をつくりやすい，また切除範囲を大きくする と valgus 変形をつくる.などがあげられよう.

そこでわれわれは比較的年少児では Evans 手術の 変法として踵立方関節を温存する踵骨頸部外転骨切り 術を試みた．その結果は 1 例を除き充分満足出来る結 果を得た.

今後矯正位保持能力, および 距骨下関節 の anterior facet の影響について経過観察してゆきたいと 考えている.

\section{結語}

遺残内反変形に対する Evans 手術は有効であるが 踵立方関節を固定することによる disadvantage は 避けられない，また年少者は偽関節をつくりやすい，

そこでわれわれは踵立方関節を温存し，踵骨頸部を 外転位に骨切りする方法を 5 例 6 足に試みたので報告 した.

\section{文献}

1) Curtis F. E.: Decancellation of the os 
calcis, astragalus, and cuboid in correction of congenital talipes equinovarus. J. Bone \& Joint Surg., 16: 110, 1934.

2) Evans D.: Relapsed club foot. J. Bone \& Joint Surg., 43-B : 722, 1961.

3) Fredehagen H.: Der Klumpbu*, Vorkommen, Anatomil, Behandlung und Spätresultate. Z. Orthop., 85: 305, 1954.

4) Johanning K.: Excochleatio ossis cuboi- dei in the treatment of pes equino-varus. Acta orthop. scandinav., 27: 310, 1958.

5) Lichtblau S.: A Medial and Lateral Release Operation for Club-Foot. 55-A : 1377, 1973.

6) Ogston A.: A New Principle of Curing Club-Foot in Severe Cases in Children a Few Years Old. The Britisch Medical Journal, 1524, 1902. 